\title{
Feasibility of urban waste for constructing Technosols for plant growth
}

\author{
Blanca Prado ${ }^{1,2,{ }^{*}}$, Lucy Mora ${ }^{1,2}$, Thalita Abbruzzini' ${ }^{1}$, Sebastian Flores ${ }^{3}$, Silke Cram ${ }^{4}$, \\ Pilar Ortega ${ }^{1}$, Armando Navarrete ${ }^{5}$, and Christina Siebe ${ }^{1,2}$
}

\author{
${ }^{1}$ Instituto de Geología, Universidad Nacional Autónoma de México, \\ Av. Universidad 3000, Coyoacán, C.P. 04510, Mexico City, Mexico. \\ ${ }^{2}$ Laboratorio Nacional de Geoquímica y Mineralogía (LANGEM), Instituto de Geología, \\ Universidad Nacional Autónoma de México, Av. Universidad 3000, Coyoacán, C.P. 04510, Mexico City, Mexico. \\ ${ }^{3}$ Posgrado en Ciencias de la Tierra, Universidad Nacional Autónoma de México, \\ Av. Universidad 3000, Coyoacán, C.P. 04510, Mexico City, Mexico. \\ ${ }^{4}$ Instituto de Geografía, Universidad Nacional Autónoma de México, \\ Av. Universidad 3000, Coyoacán, C.P. 04510, Mexico City, Mexico. \\ ${ }^{5}$ Instituto de Investigaciones en Ecosistemas y Sustentabilidad, Universidad Nacional Autónoma de México, \\ Antigua Carretera a Pátzcuaro 8701, Col. Ex Hacienda de San José de la Huerta, C.P. 58190, Morelia, Michoacán, Mexico. \\ *bprado@geologia.unam.mx
}

\begin{abstract}
An alternative for sustainable urban development is to revegetate cities with the construction of planters as well as to recover degraded sites. The objective of this work was to characterize urban waste materials produced in Mexico City and to evaluate their potential for constructing Technosols for plant growth, as an alternative to use in revegetating the city without affecting natural landscapes. Construction and demolition waste materials amended with different application rates of compost made out of gardening wastes from Mexico City green areas were tested. Nine mixtures were prepared; three based on concrete, three based on demolition waste and three based on excavation waste. Changes on physical, chemical and physicochemical properties of these mixtures, namely nutrient contents, water retention and aeration capacity, were monitored in a twelve-month experiment. The mineralogy and the risk regarding the release of heavy metals and trace elements were also evaluated in the soluble fraction. The constructed Technosols were appropriate, to a greater or lesser extent, for tomato plant growth. Soil $\mathrm{pH}$ and soil electrical conductivity (EC) were the main factors defining their suitability; both parameters changed over time due to the washing of salts. The particle size of the mineral materials as well as the application rates of compost used in the construction of the Technosols resulted in adequate water holding capacity and soil aeration for plant growth. The type of parental materials defined the majority of the Technosol characteristics as well as their ability to function as a plant support. The concentrations of readily available heavy and trace metals were not a limitation for plant growth. However, potential co-transport of these elements with soluble organic matter should be considered in further research.
\end{abstract}

Key words: C\&D waste; compost; sustainable urban development; urban soils; Technosols.

\section{RESUMEN}

Una alternativa para el desarrollo urbano sostenible es revegetar ciudades con la implementación de jardines, así como recuperar sitios degradados. El objetivo de este trabajo fue caracterizar los materiales de desecho urbano producidos en la Ciudad de México y evaluar su potencial para construir Tecnosoles para el crecimiento de las plantas, como una alternativa para revegetar la ciudad sin afectar los paisajes naturales. Se analizaron materiales de desecho de la construcción y demolición enmendados con diferentes tasas de aplicación de compost hecho con desechos de jardinería de las áreas verdes de la Ciudad de México. Se prepararon nueve mezclas; tres basadas en concreto, tres basadas en desechos de demolición y tres basadas en desechos de excavación. Los cambios en las propiedades físicas, químicas y fisicoquímicas de estas mezclas, a saber, el contenido de nutrientes, la retención de agua y la capacidad de aireación, se monitorearon en un experimento de doce meses. La mineralogía y el riesgo con respecto a la liberación de metales pesados y oligoelementos también se evaluaron en la fracción soluble. Los Tecnosoles construidos fueron apropiados, en mayor o menor medida, para el crecimiento de la planta de tomate. El pH del suelo y la conductividad eléctrica (CE) fueron los principales factores que definieron su idoneidad; ambos parámetros cambiaron con el tiempo debido al lavado de sales. El tamaño de partícula de los materiales minerales, así como las tasas de aplicación de compost utilizadas en la construcción de los Tecnosoles, resultaron en mezclas con una capacidad de retención de agua y aireación del suelo, adecuados para el crecimiento de las plantas. El tipo de materiales parentales definió la mayoría de las características de los Tecnosoles, así como su capacidad para funcionar como soporte de plantas. Las concentraciones de metales pesados fácilmente disponibles no fueron una limitación para el crecimiento de las plantas. Sin embargo, el posible co-transporte de estos elementos con materia orgánica soluble debe considerarse en futuras investigaciones. 
Palabras clave: desechos de la construcción; desarrollo urbano sostenible; suelos urbanos; Tecnosoles.

\section{INTRODUCTION}

Nowadays, about $60 \%$ of the world's population lives in urban areas and it is estimated that, by 2050, it will reach $80 \%$ (UN, 2018). It is also estimated that, by then, the world population will exceed 9 billion people (UN, 2019). The expected increase in world's population and consequent rapid urbanization will exert pressure on soil resources by causing soil degradation and pollution, as well as the reduction of green and water recharge areas, besides threatening recreational space and social living (De Kimpe and Morel, 2000; Morel et al., 2015).

An alternative for sustainable urban development is to revegetate cities with the construction of planters and green roofs, as well as to recover contaminated and/or degraded sites. However, this practice demands a large amount of soil or substrates that are frequently imported from pristine periurban areas (Séré et al., 2008; Rokia et al., 2014), thereby deteriorating natural systems that represent buffer zones or protected natural areas. Therefore, it is important to have proposals that meet the demand of substrates for revegetation without affecting natural landscapes.

Another major consequence of urbanization is the generation of organic and inorganic solid wastes. Among these wastes are those of domestic and industrial origin, as well as those generated by the construction industry; the latter constitutes different kinds of construction debris and excavation materials with diverse compositions. In this sense, in Mexico City, 2.38 thousands of tons of the excavation waste (clays and granular sediments, volcanic tuff) are produced per year; while concrete (poles, sand, mortar, asphalt) and debris (fragments of block, paving stone, bricks, concrete pipes, and stones) are produced in about 1.5 thousands of tons per year (CMIC, 2018). In Mexico City, an average of 6.5 tons day ${ }^{-1}$ of these wastes is produced (PGIRS 2016-2020). Of this total, it is estimated that $41 \%$ are organic waste; the remaining is mostly represented by waste derived from the construction industry. Construction waste includes materials such as concrete, bricks, roof tiles and ceramic wares, wood, glass, plastic materials, asphaltic blends, coal tar and tarred products, excavated soil, insulating materials, gypsum, etc. (Iacoboaea et al., 2019).

Another kind of construction waste is excavation material, which consists of soils and sediments which need to be retrieved in order to install building foundations, cellars, belowground parking lots, etc. Also, urban infrastructure such as tunnels and deep drainage systems generate large quantities of excavation materials. Excavation materials mostly consist of uncontaminated sediments with a relatively large proportion of fine particles $(<0.2 \mathrm{~mm})$. Cities are frequently settled in fluvial, lacustrine or coastal plains, i.e., in relatively flat surfaces close to water bodies. The sediments in these sites often contain small to medium amounts of organic matter due to their fluvial, lacustrine or marine origin. Due to these properties, excavation materials are potential candidates for urban soil construction, but have been very little appreciated and used (Magnusson et al., 2015).

The worldwide production of construction and demolition (C\&D) waste has increased considerably during the last decades. Nevertheless, only small fractions are recycled (Gálvez-Martos et al., 2018), which has caused environmental problems as a result of uncontrolled dumping of these materials in landfills and illegal waste disposal sites (Prieto García et al., 2012). Some countries have generated regulations regarding the disposal of these materials (Table 1), but in most cities, construction wastes are dumped in periurban areas, thereby deteriorating natural soils.

In this regard, constructed Technosols are a viable solution for urban waste management. Although urban soils very often lack biological, chemical and physical fertility to support plant growth (Morel et al., 2005), some researchers have focused on designed assemblages of technogenic materials (e.g., C\&D waste mixed with composted organic urban waste) to produce Technosols, since they could be used to improve urban ecosystem services by mimicking functions of natural soils (Morel et al., 2015, Pruvost, 2018) and to reduce the impact of cities on the environment (Deeb et al., 2016). They are expected to provide provisioning services ranging from non-food biomass used for the production of energy and fiber to food biomass production (e.g., roof gardening); regulating services such as improved water runoff and quality, maintenance of biodiversity, mitigation of pollution and improved air quality (e.g., capture of greenhouse gases and particulate

Table 1. Generation of Urban Solid Wastes in different countries and their main cities: the proportion of construction and excavation waste and progress in their management.

\begin{tabular}{|c|c|c|c|}
\hline Country (City) & $\begin{array}{l}\text { Municipal solid wastes } \\
\text { (Thousands of tons per year) }\end{array}$ & $\begin{array}{l}\text { Demolition and } \\
\text { excavation waste } \\
\text { (\% of total solid waste) }\end{array}$ & Comments on local regulations \\
\hline $\begin{array}{l}\text { Unites States of } \\
\text { America (New York) }\end{array}$ & $569000(32000)$ & $25-45 \%^{(1)}$ & $\begin{array}{l}\text { In the US, the EPA regulates the management of urban solid waste, since } 2012 \text {. } \\
\text { There are different management techniques, many of them led by private } \\
\text { recycling companies }{ }^{(1)} \text {. }\end{array}$ \\
\hline China (Beijing) & $220000(4000)$ & $50 \%^{(2,3)}$ & $\begin{array}{l}\text { There are laws regulating the management of urban solid waste, since } 2003 \text {. Out } \\
\text { of the total, only the } 16 \% \text { is recycled }{ }^{(2)} \text {. }\end{array}$ \\
\hline Brazil (Sao Paulo) & $80000(6000)$ & $10.7 \%^{(4,5)}$ & $\begin{array}{l}\text { There are laws regulating the management of urban solid waste, since } 2010 \text {. Out } \\
\text { of the total, only the } 25 \% \text { is recycled }{ }^{(4,5)} \text {. }\end{array}$ \\
\hline Russia(Moscow) & 60000 to $70000(2400)$ & $5-10 \%^{(6,7,8)}$ & $\begin{array}{l}\text { Laws regulating the management of urban solid waste started in } 2012 \text {. Only the } \\
10 \% \text { of the total is recycled }{ }^{(7,8)} \text {. }\end{array}$ \\
\hline Mexico (Mexico City) & 53000 to $103000(4700)$ & $46.95 \%{ }^{(9,10)}$ & $\begin{array}{l}\text { The regulation for managing the urban solid wastes started in 2011, out of the } \\
\text { total, only } 3 \% \text { is recycled }{ }^{(11)} \text {. }\end{array}$ \\
\hline Germany & 51000 & 55 to $63 \%^{(11,12)}$ & $\begin{array}{l}\text { The Federal Environment Ministry regulates the management of the urban } \\
\text { wastes since } 1996 \text {. Out of the total, } 70 \% \text { is recycled. }\end{array}$ \\
\hline
\end{tabular}

\footnotetext{
${ }^{(1)}$ Gruzen, 2003; (2) Mingming, 2010; ${ }^{(3)}$ Zhao and Rottler, 2008; ${ }^{(4)}$ Jacobi and Besen, 2011; ${ }^{(5)}$ Alfaia et al., 2017; ${ }^{(6)}$ IFC, 2012; ${ }^{(7)}$ Davlasyan, 2020; ${ }^{(8)}$ Villanueva, 2019; ${ }^{(9)}$ PGIRS, 2016-2020; ${ }^{(10)}$ Rojas Valencia and Macías Martínez, 2013; ${ }^{(11)}$ Eurostat Statistics Explained, 2020; ${ }^{(12)}$ Federal Ministry for the Environment Nature Conservation and Nuclear Safety, 2020.
} 
matter by plant foliage), local climate (e.g., control of urban temperature, local thermal insulation), carbon (C) storage, and conservation of the natural soil capital (i.e., by the use of secondary materials for soil construction) (Morel et al., 2015; Deeb et al., 2016; Grard et al., 2018; Deeb et al., 2016).

Nevertheless, previous studies have shown that each material used to design constructed Technosols should be carefully considered due to the high chemical reactivity of many anthropogenic materials, which determines several soil chemical, physical and physicochemical properties. Among these, particle size distribution is a determinant of soil water retention (particle sizes $<0.02 \mathrm{~mm}$ ), but also of water infiltration and soil drainage capacity (particle sizes $>0.02 \mathrm{~mm}$ ). Compaction is a known problem in constructed Technosols, which reduces the total pore volume, water and air circulation (Gregory et al., 2006; Cannavo et al., 2014; Vidal-Beaudet et al., 2017). The contents of carbonates, particle size distribution (texture) and organic C influence the soil's buffer capacity and the potential of nutrient provision to plants. The excess of soluble salts inhibits microbial activities and plant growth, and high concentrations of heavy metal contents endanger soil functioning (Paradelo and Barral, 2013; Rokia et al., 2014; Greinert and Kostecki, 2019).

Another difficulty is to establish the adequate proportion of different waste materials so that the resulting Technosol achieves the targeted urban soil functions. Thus, the objective of this work was to characterize different urban waste materials produced in Mexico City and to test different mixtures of these in order to evaluate their potential to support plant growth. We tested not only construction debris, but also excavation materials, which were amended with different doses of compost made out of gardening wastes from green city areas. Our hypothesis is that excavation materials are especially valuable substrates for Technosol construction, since they contain fine particles and organic matter, which provide nutrients like $\mathrm{K}, \mathrm{Ca}$ and $\mathrm{Mg}$ and thus higher cation exchange capacity. However, coarser materials as C\&D debris need to be added to ensure quick drainage and avoid compaction, as well as organic materials to supply $\mathrm{C}$ and N. C\&D debris can be an interesting option for the construction of Technosols because they can be crushed to any particle size to achieve a certain moisture retention capacity and soil infiltration capacity, as well as for its content of essential nutrients for the plant growth, such as $\mathrm{Ca}, \mathrm{Mg}, \mathrm{K}, \mathrm{Fe}, \mathrm{Cu}$ and $\mathrm{Zn}$.

\section{MATERIALS AND METHODS}

\section{Feedstocks for the construction of Technosols}

Technosols were manufactured with construction wastes, namely concrete, demolition and excavation waste. Concrete waste is a mix of clinker (product of calcinations at $1450^{\circ} \mathrm{C}$ of limestone and clay), plaster and additives embedded with steel or iron bars. Demolition waste materials are a mixture of construction waste materials; e.g., concrete, masonry, bricks, blocks, and ceramics. Excavation waste refers to the natural material extracted during the preparation of the land prior to the construction of a building.

Many of the world's largest cities are built in valleys or river banks; therefore, their excavation materials correspond mainly to sediments of different granulometry. The natural lacrustrine deposits of Mexico City are heterogeneous; with an alluvial, volcanic and colluviums origin, the particle size distribution of the excavation materials changes depending on the excavation depth. However, the grain size is predominantly clayey silt, with residues of organic matter (Díaz-Rodriguez, 2006).

The three kinds of waste materials were supplied by the company Concretos Reciclados S.A. de C.V., which is based in Mexico City, and it is dedicated to recycling of C\&D materials. Likewise, materials that favor the availability of nutrients at different time scales were considered and, therefore, "Tepetate" was added to all mixtures, since this is an inorganic waste material of natural origin that, given its volcanic origin, brings together chemical and physical properties favorable for the development of plants (Prat et al., 1997). Tepetate is the indurated subsoil horizon developed in tephrous materials in various parts of the Trans-Mexican Volcanic Belt. Tepetate's compaction and/or cementation, which occur due to different processes, result in its high bulk density (1.7-1.9 $\left.\mathrm{g} \cdot \mathrm{cm}^{-3}\right)$ and low porosity $(<24 \%)$, low hydraulic conductivity, and low moisture retention that characterized this material. Regarding the chemical characteristics, Tepetate has low contents of organic matter, nitrogen, and phosphorus (Flores Román et al. 1991; 2011) and constitutes an excavation waste during drilling in the construction industry. In fact, it is considered a construction waste by the Mexican Chamber of the Construction Industry (CMIC, 2018). Organic carbon and nitrogen were added to Technosols through the application of green waste compost. The compost was produced from aerobic composting of grass mowing residues mixed with tree and shrub trimmings from green areas within the city. The compost produced complies with the characteristics indicated in the official Mexican Standard (NADF-020-AMBT-2011) for vivarium substrate and potting soil substitute.

\section{Characterization of feedstocks and design of Technosols}

Each individual material (feedstock) was physically and chemically characterized. The proportions used of the different feedstocks were calculated to obtain Technosols with favorable properties to fulfill their function as plant support media, such as adequate water holding capacity and aeration, $\mathrm{pH}$, electrical conductivity (EC) and availability of nutrients. On a macroscopic scale, the sizes of inorganic particles were obtained by crushing to fragments from $1 \mathrm{~mm}$ to $10 \mathrm{~mm}$, and the proportion of these materials in Technosols was based on a greater or lesser aeration/moisture retention capacity.

Nine mixtures were prepared, three based on concrete, three based on demolition waste, and another three based on waste from excavations (Figure 1). Three application rates of either construction waste and compost were used in order to evaluate the changes on physical, chemical and physicochemical properties in the mixtures, namely the nutrient contents, the water retention and aeration capacity, which varied by 55,45 and $35 \%$ and by 10,20 and $30 \%(v / v)$, respectively

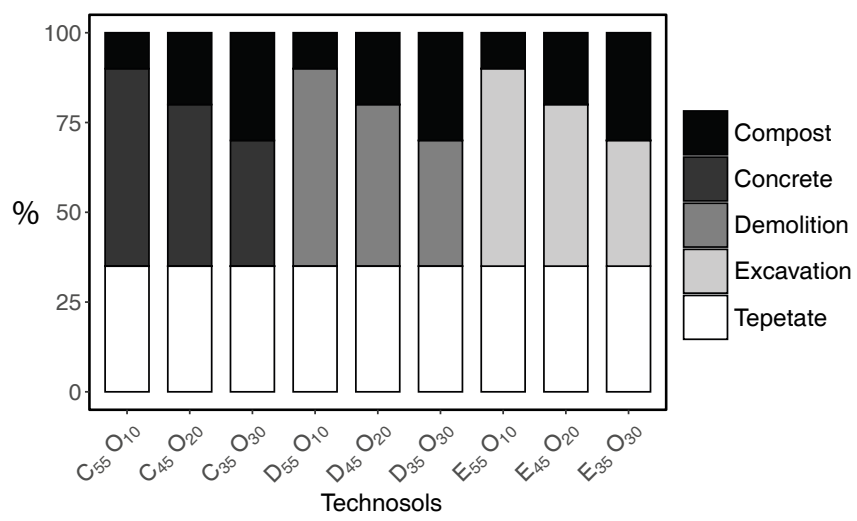

Figure 1. Proportions of inorganic and organic feedstocks used in the construction of nine Technosols. C is concrete; $\mathrm{D}$ is demolition waste; $\mathrm{E}$ is excavation waste; $\mathrm{O}$ is compost. The numbers that follow each letter represent the proportion of the feedstocks used to produce the Technosols. The percentage of Tepetate was $35 \%$ in all Technosols. 
(Figure 1). The proportion of Tepetate was constant in all mixtures (35\%, $\mathrm{v} / \mathrm{v})$. For the preparation of each mixture, the volume of feedstocks were measured and homogenized. Then, they were placed in $50 \times 30 \times 10$ $\mathrm{cm}$ (length $\times$ width $\times$ height) pots with three replicates per treatment $(\mathrm{n}=3)$. Prior to the experiments, a subsample of $500 \mathrm{~g}$ of each final mixture was taken for its characterization.

\section{Physical characterization of feedstocks and Technosols}

The determination of particle density of solids (mean particle density) $\left(\rho_{s}\right)$ was carried out on both individual materials and Technosols using the pycnometer method (Blake, 1965). For the bulk density $\left(\rho_{d}, \mathrm{~g} \cdot \mathrm{cm}^{-3}\right)$, undisturbed samples $(5 \mathrm{~cm}$ in diameter, $5 \mathrm{~cm}$ in height) were taken, the parameter was calculated from the mass of the dry soil at $105^{\circ} \mathrm{C}$ for $48 \mathrm{~h}$ and the cylinder volume (Blake, 1965). The porosity $(\phi)$ of these was obtained by the following equation:

$$
\phi=1-\frac{\rho_{d}}{\rho_{s}}
$$

The relative proportions of sand, silt and clay size particles in the individual materials were determined by the Bouyoucos hydrometer method (Gee and Bauder, 1986). The maximum water holding capacity in the individual materials was determined from $30 \mathrm{~g}$ of the dry material was saturated an allowed to drain for 24 hours (Schinner et al., 1993), while in the Technosols this was evaluated gravimetrically in containers under experimental conditions. The moisture content was monitored daily for a period of 60 days using a time-domain reflectometry (TDR) probe (HH2 Delta Devices) as well as gravimetrically by recording the weight difference of the experimental units from one day to the next. The soil matric potential was monitored by using gypsum blocks connected to a data logger (Irrometer Water Mark 900M). The experimental data were adjusted to the van Genuchten (1980) water retention model, using the SWRC Fit program (Seki, 2007). The drainage capacity of the Technosols was directly evaluated in the experimental containers and its saturated hydraulic conductivity was determined in steel cylinders with a volume of $100 \mathrm{~cm}^{3}$, calculated as follows:

$$
K s=\left(\frac{Q}{A t}\right) \times\left(\frac{l}{H}\right)
$$

where: $K s$ represents the saturated hydraulic conductivity $\left(\mathrm{cm} \cdot \mathrm{h}^{-1}\right) ; \mathrm{Q}$ is the volume collected by the cylinder $\left(\mathrm{cm}^{3}\right) ; A$ is the area of the metallic cylinder $\left(\mathrm{cm}^{2}\right)$; $t$ is the elapsed time, in hours, until the $Q$ value is obtained; $l$ is the height of the metal cylinder $(\mathrm{cm})$ and; $H$ is the height of the cylinder to the drainage tube $(\mathrm{cm})$.

\section{Chemical characterization of feedstocks and Technosols}

The chemical characterization of the feedstocks and Technosols was carried out by standard methods for soil analyses, van Reeuwijk (1992). The $\mathrm{pH}$ and $\mathrm{EC}$ were measured by the potentiometric method in a 1:2.5 ratio (soil:solution) using a potentiometer (Beckman) and a conductimeter (LaMotte, CON 6), respectively. The determinations of total carbon $(\mathrm{C})$ and nitrogen $(\mathrm{N})$ contents were carried out by the total combustion method on previously fine grounded and dried $\left(60{ }^{\circ} \mathrm{C}\right)$ materials for $24 \mathrm{~h}$, using a CNHS/O elemental analyzer (Perkin Elmer 2400 series II).

The elemental composition of the soluble fraction was carried out in the supernatant of a saturation paste, made with $300 \mathrm{~g}$ of dry material saturated with distilled water. After 24 hours of equilibration, the pore water was extracted using a vacuum pump. The major elements were determined by ion chromatography (Waters model 1525). For the determination and quantification of anions in the samples, a $4.6 \times 75 \mathrm{~mm}$ (length $\times$ width) IC-PaK ${ }^{\infty}$ column (Waters) was used as stationary phase, using as a mobile phase a solution of acetonitrile:butanol:sodium borate gluconate:water in a 12:2:2:84 ratio in isocratic mode at a flow of $1 \mathrm{ml} \cdot \mathrm{min}^{-1}$. The anions evaluated were bicarbonate $\left(\mathrm{HCO}_{3}^{-}\right)$, chloride $(\mathrm{Cl})$, nitrate $\left(\mathrm{NO}_{3}{ }^{-}\right)$and sulfate $\left(\mathrm{SO}_{4}{ }^{2-}\right)$. For the determination and quantification of cations in the samples, a $4 \times 100 \mathrm{~mm}$ (length $\times$ width) Metrosep $\mathrm{C}^{\circ}$ column (Metrohm) was used as stationary phase, and a solution of $1.9 \mathrm{mM} \mathrm{HNO}_{3}$ was used as the mobile phase $0.8 \mathrm{mM}$ Dipicolinic acid in Isocratic mode at a flow of $0.9 \mathrm{ml} \cdot \mathrm{min}^{-1}$. The cations evaluated were calcium $\left(\mathrm{Ca}^{2+}\right)$, magnesium $\left(\mathrm{Mg}^{2+}\right)$, potassium $\left(\mathrm{K}^{+}\right)$, sodium $\left(\mathrm{Na}^{+}\right)$and ammonium $\left(\mathrm{NH}_{4}^{+}\right)$.

The availability of soluble compounds of inorganic and organic carbon (DIC and DOC, respectively) was evaluated in an aliquot of the saturation paste extract by the wet catalytic combustion method, in which the total carbon is brought to $700{ }^{\circ} \mathrm{C}$ in the presence of a catalyst (Pt02) and a high purity air stream. The inorganic carbon is pre-bubbled with $1 \mathrm{M} \mathrm{HCl}$ and then, in the bubbled air, the $\mathrm{CO}_{2}$ is quantified with an infrared detector. Total organic carbon is calculated as the difference between total carbon and inorganic carbon. The risk regarding the release of heavy metals and trace elements was evaluated in the soluble fraction extracted from the saturation paste using the EPA 6010C method with inductively coupled plasma-optical emission spectrometry (ICP-OES) and a Perkin Elmer 8300 analyzer. For this analysis, the evaluated metals were aluminum $(\mathrm{Al})$, iron $(\mathrm{Fe})$, copper $(\mathrm{Cu})$, molybdenum $(\mathrm{Mo})$, manganese $(\mathrm{Mn})$, vanadium $(\mathrm{V})$, nickel $(\mathrm{Ni})$, and chromium $(\mathrm{Cr})$.

\section{Mineralogy}

The mineral phase saturation index was calculated using the Visual MinteQ 2013 software. The input data of the model were the results of the analysis of major elements by high performance liquid chromatography (HPLC), which was measured in the supernatant of the saturation paste that was also used to estimate the electrical conductivity and concentrations of major ions.

\section{Evaluation of Technosols as plant growth media}

To evaluate plant biomass production in Technosols, tomato plants were cultivated in $1 \mathrm{~kg}$ pots for each Technosol using triplicates $(n=3)$. Commercial seeds of cherry tomato (Lycopersicon lycopersicum var. cerasiforme) were used in the experiment. The seeds were germinated in small containers in the same substrate in which they grew. Once the seedling was of adequate size (around $7 \mathrm{~cm}$ ), they were transplanted into the experimental containers. The plants were grown under greenhouse conditions at a controlled temperature of $25^{\circ} \mathrm{C}$ for a period of 90 days. The growth of tomato plants in each treatment was evaluated periodically by measuring the plant height and, at the end of the experimental period; the dry weight of aboveground biomass (shoots) was also evaluated. For dry weight determination, plant shoots were separated and dried at $50{ }^{\circ} \mathrm{C}$ to constant weight.

\section{Statistical analyses}

The differences in physical, chemical and physicochemical properties among the distinct Technosols were evaluated by an ANOVA according to the experimental design (completely randomized design, CRD) with two levels, i.e. 1) the type of parent material (comparisons between the three groups of Technosols - concrete, demolition and excavation; and 2) the compost application rates, regardless of the parent material - namely comparisons among Technosols with $10\left(\mathrm{O}_{10}\right), 20$ $\left(\mathrm{O}_{20}\right)$ and $30 \%\left(\mathrm{O}_{30}\right)$ of compost. Moreover, the interactions between physical, chemical and physicochemical variables of Technosols were explored by a Principal Component Analysis (PCA). Additionally, generalized linear models (GLM) were applied to assess the effect of the properties of Technosols on the height and dry weight of tomato plants. All analyzes were run using the software R Core Team, 2020. 


\section{RESULTS AND DISCUSSION}

\section{General characteristics of the feedstocks}

The inorganic feedstocks used in the preparation of Technosols were mostly constituted of sand- $(65 \pm 9)$ and silt- (31 \pm 8$)$ sized particles over those of clay size ( $4 \pm 2$ ), thus having a sandy-loam texture, while the Tepetate has loamy texture (Figure 2). Nevertheless, the homogeneity of distribution size resulted in little variation of bulk density among C\&D waste, ranging from 1.3 to $1.5 \mathrm{~g} \cdot \mathrm{cm}^{-3}$. The particle density values of the inorganic materials varied between 2.2 and 2.9 $\mathrm{g} \cdot \mathrm{cm}^{-3}$, thus being similar to the values found in natural soils (around $2.65 \mathrm{~g} \cdot \mathrm{cm}^{-3}$ ) (Figure 3). Indeed, construction waste can also contain actual soil, as well as various building debris, etc. which may partially explain the observed result. As expected, the bulk and particle densities of compost were much lower than that of mineral materials ( 0.5 and $1.5 \mathrm{~g} \cdot \mathrm{cm}^{-3}$, respectively) (Figure 3 ).

The field capacity varied little among construction wastes (ranging from 24 to $28 \%$ ), while Tepetate and compost presented much higher field capacity values, of 48 and $53 \%$, respectively (Figure 3). The porosity of the inorganic feedstocks was between 50 and $55 \%$, while the compost had a porosity of $60 \%$ (Figure 3 ). Organic matter is well known for its high total porosity, of around $0.7 \mathrm{v} / \mathrm{v}$ in the case of compost (Cannavo et al., 2014), which in turn confers low bulk and specific densities, though with a much higher water holding capacity in comparison with $\mathrm{C} \& \mathrm{D}$ waste.

The organic and inorganic feedstocks are predominantly alkaline $(\mathrm{pH}>7.8)$ and, as a consequence, have high salinity (EC between 1.0 and $2.0 \mathrm{dS} \cdot \mathrm{cm}^{-1}$ in inorganic materials), in particular the compost $\left(4.3 \mathrm{dS} \cdot \mathrm{cm}^{-1}\right)$. The analysis of soluble or readily available major elements shows the abundance of anionic and cationic ions in the feedstocks (Figure 4). The compost has a greater availability of $\mathrm{NO}_{3}{ }^{-}$compared to the other feedstocks. Likewise, Tepetate has a higher concentration of available $\mathrm{HCO}_{3}{ }^{-}$compared to the $\mathrm{C} \& \mathrm{D}$ waste, which in turn presented higher concentrations of $\mathrm{SO}_{4}{ }^{2-}$. Finally, the excavation residues seem to present lower available anionic ions in comparison to the other technogenic materials. Other available ions essential for plant growth are calcium $\left(\mathrm{Ca}^{2+}\right)$ and potassium $\left(\mathrm{K}^{+}\right)$. The compost, in particular, stands out for its high $\mathrm{K}^{+}$available content. In addition, all inorganic materials appear to have a $\mathrm{Ca}^{2+}$ availability comparable to that of the compost, except for the excavation waste, which also present lower contents of available sodium (Figure 4).

The content of dissolved organic carbon (DOC) is higher in the compost compared to the construction wastes, which evidences the

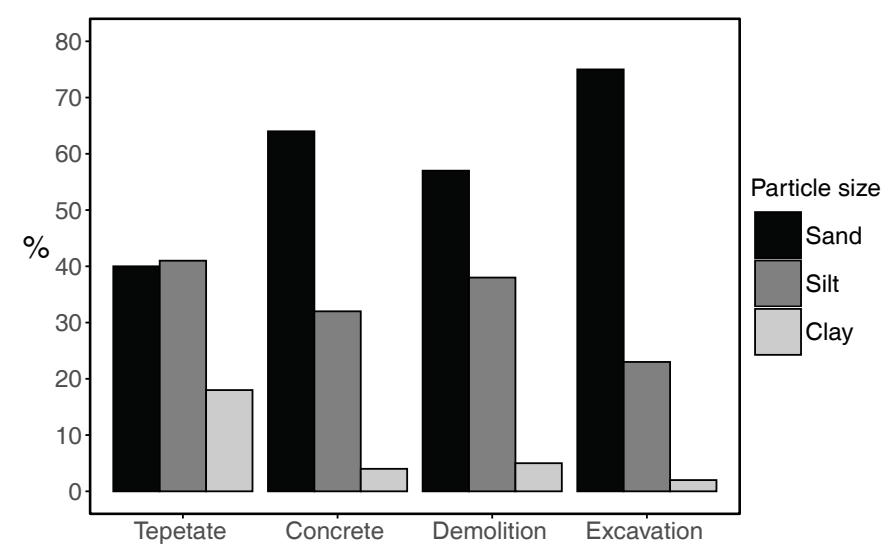

Figure 2. Relative proportions of sand, silt and clay size particles in feedstocks used for the construction of Technosols.

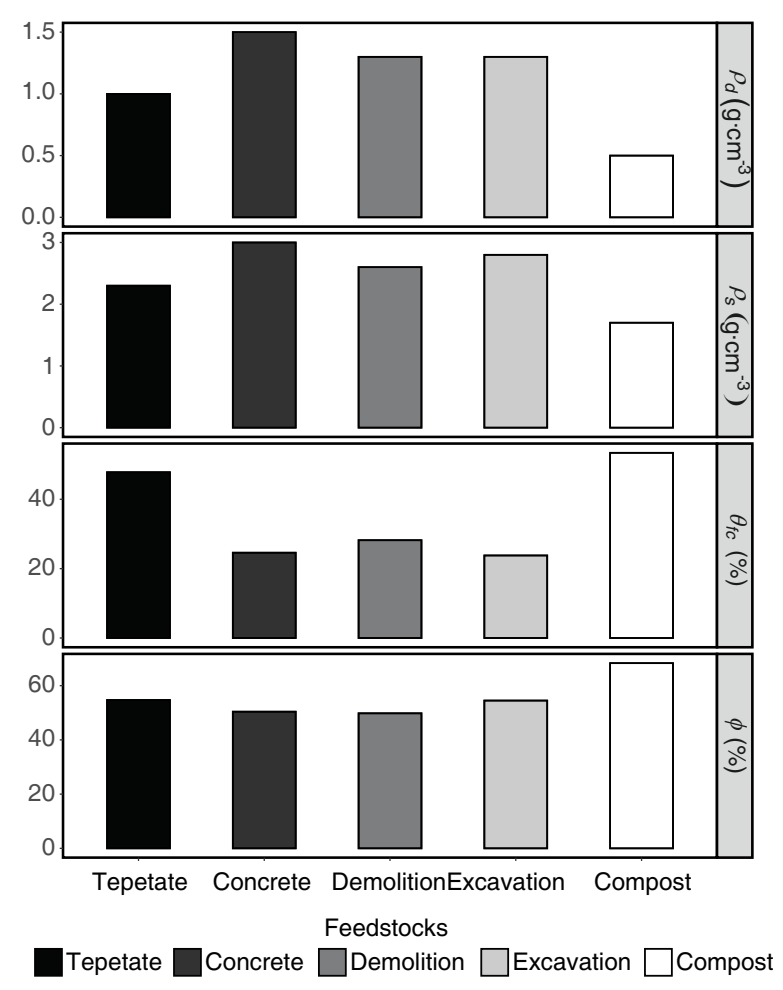

Figure 3. Bulk density $\left(\rho_{d}\right)$, particle density $\left(\rho_{s}\right)$, water retention at field capacity $\left(\theta_{f c}\right)$ and porosity $(\phi)$ of inorganic and organic feedstocks used for the construction of Technosols.

greater proportion of readily available organic carbon (OC) fractions in this material (Figure S1 in the electronic supplement). Among the C\&D waste, the demolition waste presented higher DOC compared to concrete and excavation debris. Although the concentrations of dissolved inorganic (DIC) were many orders of magnitude lower than those of DOC, the former OC fraction was higher in demolition waste compared to the other organic and inorganic feedstocks.

\section{General characteristics of the Technosols}

The bulk density of Technosols varied between 1.2 to $1.4 \mathrm{~g} \cdot \mathrm{cm}^{-3}$, being slightly higher than that of natural soils. Usually, Technosols may exhibit higher bulk density and, thus, higher compactability, compared to natural soils (Paradelo and Barral, 2013; Morel et al., 2015). However, the addition of Tepetate probably contributed to lower the bulk density of the produced Technosols. Moreover, the higher the bulk density of a soil, the more effective organic matter will be in reducing its compactability due to its higher degree of elasticity under compression forces compared to mineral particles (Zhang et al., 1997). Indeed, the bulk density of Technosols were inversely proportional to the rate of compost added ( $\mathrm{p}<0.05)$ (Table 2 ). The particle density of Technosols varied between 2.1 and $2.2 \mathrm{~g} \cdot \mathrm{cm}^{-3}$, which is relatively low compared to the values commonly found in natural soils $\left(2.65 \mathrm{~g} \cdot \mathrm{cm}^{-3}\right)$. However, there were no significant differences between concrete-, demolition- and excavation-based Technosols regarding this property $(\mathrm{p}>0.05)$ (Table 2).

\section{Water holding capacity of Technosols}

Notwithstanding the absence of relevant differences in water retention at field capacity among C\&D waste, the value of this property varied among Technosols. Once the mixtures were prepared, it was observed that the water retention capacity at field capacity of Technosols 

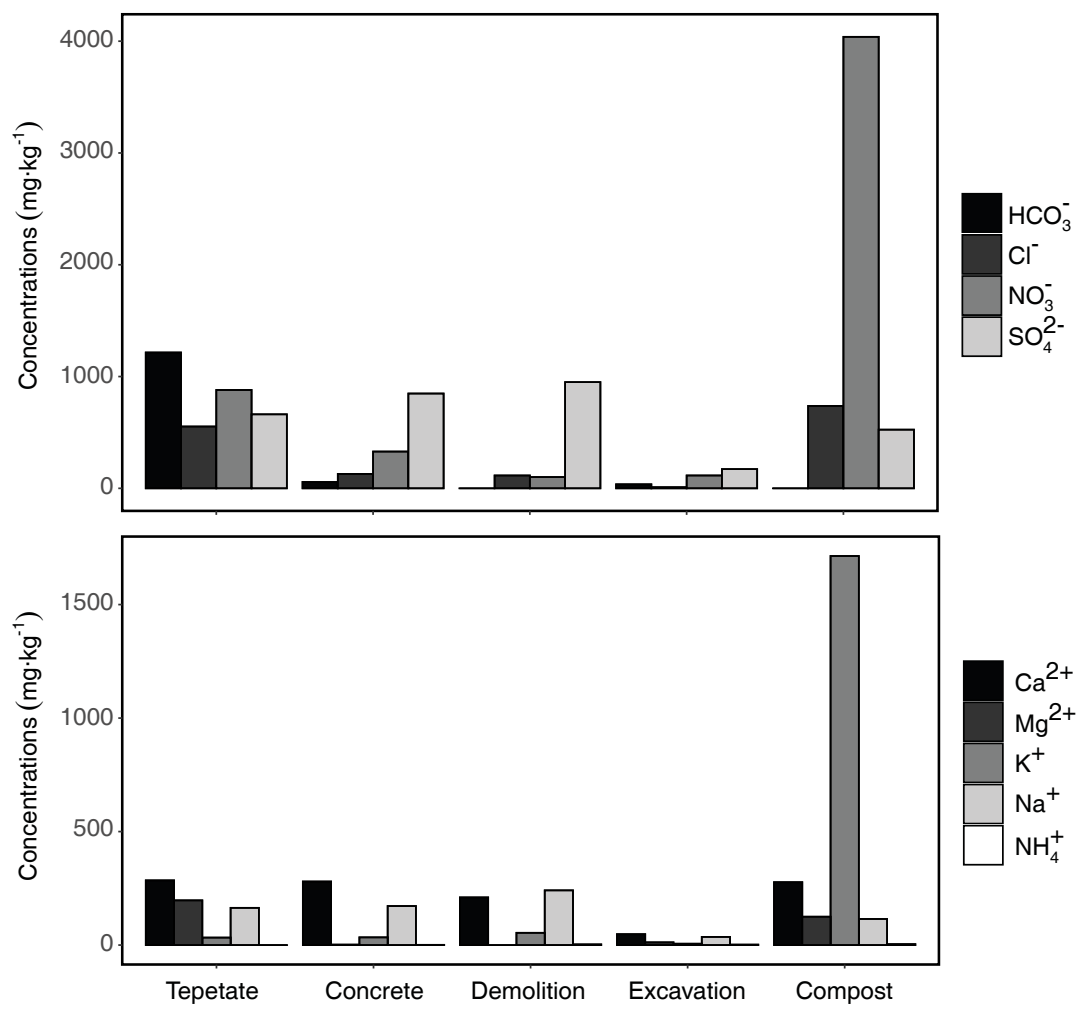

Figure 4. Distribution of major soluble ions measured in saturation paste in the feedstocks used for the construction of Technosols.

that were concrete- $\left(\mathrm{C}_{55} \mathrm{O}_{10}, \mathrm{C}_{45} \mathrm{O}_{20}, \mathrm{C}_{35} \mathrm{O}_{30}\right)$ and excavation-based $\left(\mathrm{E}_{55} \mathrm{O}_{10}, \mathrm{E}_{45} \mathrm{O}_{20}, \mathrm{E}_{35} \mathrm{O}_{30}\right)$ increased with the application rate of compost (from 28 to $36 \%$, and from 27 to $31 \%$, respectively), while, in the demolition-based Technosols $\left(\mathrm{D}_{55} \mathrm{O}_{10}, \mathrm{D}_{45} \mathrm{O}_{20}, \mathrm{D}_{35} \mathrm{O}_{30}\right)$, the moisture retention at field capacity was similar among the three rates of compost application (of around $34 \%$ ).

The greater moisture retention capacity observed in demolitionbased Technosols with a similar initial porosity value as the other Technosols, presumes a smaller pore size in these. Moreover, demolition waste contains lower sand and higher silt contents compared to the other C\&D waste, and the Tepetate contains higher clay contents in comparison with the latter materials, which may favor the formation of small pores, thus leading to greater water retention and higher susceptibility to compaction (Figure 5). Paradelo and Barral (2013) observed that the values of critical water content (the moisture corresponding to the maximum density of compaction) increased as a function of increasing compost rate. This effect was greatest for the sand-sized materials, showing that the addition of organic matter would be more effective in reducing the susceptibility to compaction of coarse- textured materials in comparison with fine textured ones.

The Figure 6 shows the evolution of the matric potential of the soil over 14 days after irrigation, measured under greenhouse conditions in the different treatments without plants. It is observed that the low and medium rates of compost additions $\left(\mathrm{O}_{10}\right.$ and $\left.\mathrm{O}_{20}\right)$ to Technosols did not seem to impact on soil moisture retention, while the high rate of compost $\left(\mathrm{O}_{30}\right)$ promoted a faster drainage, which lead to a smaller water retention in the substrate (Figure $6 \mathrm{a}$ and $6 \mathrm{~b}$ ).

When comparing Technosols made out of C\&D waste with the highest rates of compost (Figure 6c), it is observed that the concretebased Technosol presented higher aeration; this mixture takes about two days to reach the field capacity $(30 \mathrm{kPa})$, while for the other
Technosols, at least five days are required, being the demolition-based Technosol the one that presented the lowest aeration capacity (Figure 6c), which reinforces our previous findings regarding the higher compactability of demolition-based Technosols. In brief, these results highlight the importance of compost application rates in improving the pore size distribution and macroporosity, as well as the particle size of the feedstocks used in the preparation of Technosols.

\section{Physicochemical characteristics of Technosols}

One of the aspects of great concern regarding the use of C\&D waste to produce Technosols is their high pH (Rokia et al., 2014). Soil reaction is one of the most frequently noted differences between anthropogenic soils and those of natural origin (Greinert, 2015). The widespread dumping of lime containing construction waste on soil increases the $\mathrm{pH}$ values above 8 and often even 10 (Morel et al., 2005, 2015; Kawahigashi, 2017) reducing the availability of many soil nutrients (Séré et al., 2008), with consequences for plant development.

In all evaluated Technosols, the initial $\mathrm{pH}$ values were above 8 units (Figure 6). In particular, the Technosols made from demolition waste $\left(\mathrm{D}_{55}, \mathrm{D}_{45}\right.$ and $\left.\mathrm{D}_{35}\right)$ presented the highest initial $\mathrm{pH}$ (above 10 units) ( $\mathrm{p}<0.05)$ (Figure 7, Table S1 in the electronic supplement). On the other hand, the Technosols based on excavation residues $\left(\mathrm{E}_{55}, \mathrm{E}_{45}\right.$ and $\mathrm{E}_{35}$ ) had the lowest initial and final (after 90 days of pot trial) $\mathrm{pH}$ values among Technosols $(\mathrm{p}<0.05)$ (Figure 7 , Table $\mathrm{S} 1)$. It is important to point out that the rates of compost did not have significant effects on both initial and final $\mathrm{pH}$ values $(\mathrm{p}>0.05)$ (Figure 7, Table S2 in the electronic supplement). However, after 90 days of experiment with plant growth, $\mathrm{pH}$ values in demolition-based Technosols decreased by $13 \%$ compared to their initial values $(\mathrm{p}<0.05)$ and did not differ from the concrete-based Technosols ( $p>0.05$ ), while the other Technosols did not show significant changes in this property over time. 
Table 2. Bulk density $(\rho d)$, particle density $(\rho s)$, concentrations of total C and $\mathrm{N}$, and C-to-N ratio of the evaluated Technosols. $\mathrm{C}$ is concrete; $\mathrm{D}$ is demolition; $\mathrm{E}$ is excavation; $\mathrm{O}$ is compost. Means $( \pm \mathrm{SE})$ followed the same uppercase letter on the columns do not differ significantly by the Tukey test $(p<0.005)$.

\begin{tabular}{|c|c|c|c|c|c|}
\hline \multirow[t]{2}{*}{ Technosol } & $\rho_{d}$ & $\rho_{s}$ & Total C & Total N & \multirow[t]{2}{*}{$\mathrm{C} / \mathrm{N}$} \\
\hline & \multicolumn{2}{|c|}{$\mathrm{g} \cdot \mathrm{cm}^{-3}$} & \multicolumn{2}{|c|}{$\mathrm{g} \cdot \mathrm{kg}^{-1}$} & \\
\hline $\mathrm{C}_{55} \mathrm{O}_{10}$ & $1.33 \pm 0.20 \mathrm{D}$ & $2.24 \pm 1.21 \mathrm{~A}$ & $18.8 \pm 0.70 \mathrm{~B}$ & $1.23 \pm 0.05 \mathrm{~A}$ & $15.2 \pm 0.30 \mathrm{DE}$ \\
\hline $\mathrm{C}_{45} \mathrm{O}_{20}$ & $1.22 \pm 0.20 \mathrm{ABC}$ & $2.24 \pm 1.21 \mathrm{~A}$ & $24.0 \pm 0.70 \mathrm{C}$ & $1.74 \pm 0.05 \mathrm{~B}$ & $13.7 \pm 0.30 \mathrm{CD}$ \\
\hline $\mathrm{C}_{35} \mathrm{O}_{30}$ & $1.15 \pm 0.20 \mathrm{~A}$ & $2.06 \pm 1.21 \mathrm{~A}$ & $29.7 \pm 0.70 \mathrm{D}$ & $2.37 \pm 0.05 \mathrm{CD}$ & $12.5 \pm 0.30 \mathrm{BC}$ \\
\hline $\mathrm{D}_{55} \mathrm{O}_{10}$ & $1.24 \pm 0.20 \mathrm{BC}$ & $2.09 \pm 1.21 \mathrm{~A}$ & $26.7 \pm 0.70 \mathrm{CD}$ & $1.17 \pm 0.05 \mathrm{~A}$ & $22.9 \pm 0.30 \mathrm{~F}$ \\
\hline $\mathrm{D}_{45} \mathrm{O}_{20}$ & $1.20 \pm 0.20 \mathrm{ABC}$ & $2.10 \pm 1.21 \mathrm{~A}$ & $35.0 \pm 0.70 \mathrm{E}$ & $2.13 \pm 0.05 \mathrm{C}$ & $16.4 \pm 0.30 \mathrm{E}$ \\
\hline $\mathrm{D}_{35} \mathrm{O}_{30}$ & $1.16 \pm 0.20 \mathrm{AB}$ & $2.08 \pm 1.21 \mathrm{~A}$ & $35.0 \pm 0.71 \mathrm{~F}$ & $2.81 \pm 0.05 \mathrm{E}$ & $14.9 \pm 0.30 \mathrm{DE}$ \\
\hline $\mathrm{E}_{55} \mathrm{O}_{10}$ & $1.35 \pm 0.20 \mathrm{D}$ & $2.24 \pm 1.21 \mathrm{~A}$ & $35.0 \pm 0.72 \mathrm{~A}$ & $1.15 \pm 0.05 \mathrm{~A}$ & $10.1 \pm 0.30 \mathrm{~A}$ \\
\hline $\mathrm{E}_{45} \mathrm{O}_{20}$ & $1.24 \pm 0.20 \mathrm{C}$ & $2.15 \pm 1.21 \mathrm{~A}$ & $35.0 \pm 0.73 \mathrm{~B}$ & $1.72 \pm 0.05 \mathrm{~B}$ & $10.8 \pm 0.30 \mathrm{~A}$ \\
\hline $\mathrm{E}_{35} \mathrm{O}_{30}$ & $1.15 \pm 0.20 \mathrm{~A}$ & $2.16 \pm 1.21 \mathrm{~A}$ & $35.0 \pm 0.74 \mathrm{D}$ & $2.54 \pm 0.05 \mathrm{DE}$ & $11.7 \pm 0.30 \mathrm{~A}$ \\
\hline
\end{tabular}

\section{Distribution of major elements and carbon fractions in Technosols}

The analysis of readily available elements showed that calcium $\left(\mathrm{Ca}^{2+}\right)$ is the dominating cation in saturation extracts of the waste materials. Excavation- and concrete-based Technosols have soluble magnesium $\left(\mathrm{Mg}^{2+}\right)$ contents that were 22-fold higher compared to demolition-based Technosols (Figure 8). However, the latter had a concentration of soluble sodium $\left(\mathrm{Na}^{+}\right)$that was $86 \%$ higher compared to excavation-based Technosols (Figure 8). This is reflected in the soil's electrical conductivity because $\mathrm{Na}^{+}$has a high mobility (Jordán et al., 2017). The proportional distribution of soluble ions shows that these are distributed according to the proportion of the materials added. The $\mathrm{NO}_{3}{ }^{-}, \mathrm{SO}_{4}{ }^{2-}$ and $\mathrm{HCO}_{3}{ }^{-}$ions were the most abundant in all samples and, in particular, the concentrations of $\mathrm{SO}_{4}{ }^{2-}$ were higher in the

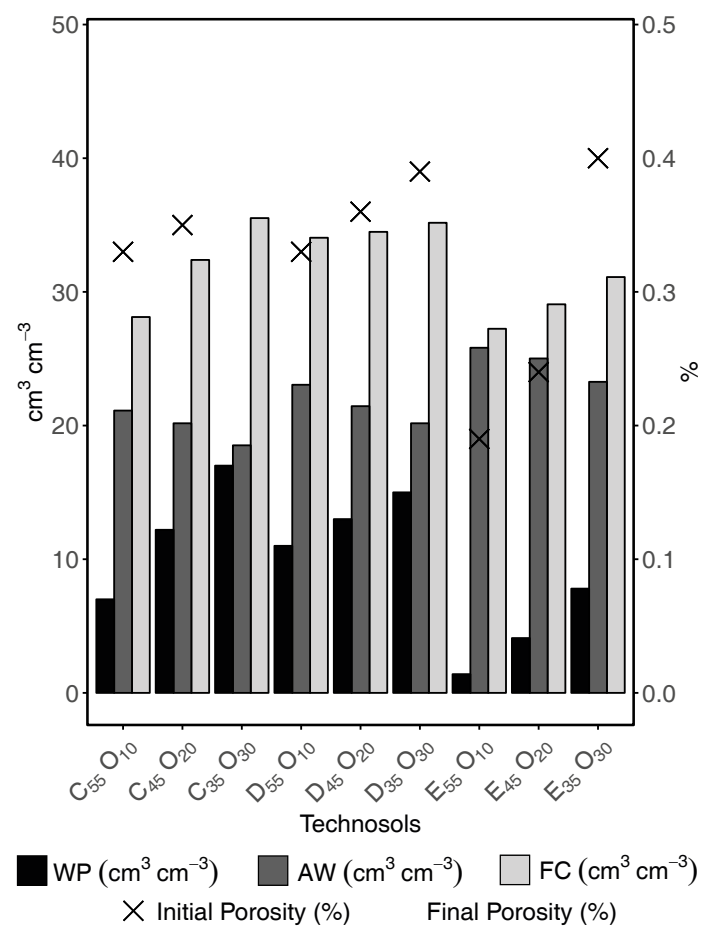

Figure 5. Wilting point (WP), plant-available water (AW), field capacity (FC), and initial and final porosity of Technosols. $\mathrm{C}$ is concrete; $\mathrm{D}$ is demolition; $\mathrm{E}$ is excavation; $\mathrm{O}$ is compost. concrete- $\left(\mathrm{C}_{55}, \mathrm{C}_{45}, \mathrm{C}_{35}\right)$ and demolition-based Technosols $\left(\mathrm{D}_{55}, \mathrm{D}_{45}\right.$, $\left.\mathrm{D}_{35}\right)$ compared to excavation-based Technosols $(\mathrm{p}<0.05)$.

Increasing application rates of compost have also influenced the concentrations of soluble cationic and anionic ions. In this case, the concentrations of $\mathrm{K}^{+}, \mathrm{NO}_{3}{ }^{-}$and $\mathrm{Cl}^{-}$in the Technosols with the highest dose of compost $\left(\mathrm{C}_{35} \mathrm{O}_{30}, \mathrm{D}_{35} \mathrm{O}_{30}\right.$ and $\left.\mathrm{E}_{35} \mathrm{O}_{30}\right)$ have increased by 293 , 168 and $97 \%$, respectively, compared to the Technosols with the lowest application rates $\left(\mathrm{C}_{55} \mathrm{O}_{10}, \mathrm{D}_{55} \mathrm{O}_{10}\right.$ and $\left.\mathrm{E}_{55} \mathrm{O}_{10}\right)(\mathrm{p}<0.05)$ (Figure 8 , Tables $\mathrm{S} 3$ and $\mathrm{S} 4$ in the electronic supplement), regardless of the construction material.

It is important to mention that the distribution of major ions in solution represents an important contribution of nutrients for plant growth, including ions such as $\mathrm{NO}_{3}^{-}, \mathrm{SO}_{4}{ }^{2-}$ and $\mathrm{HCO}_{3}{ }^{-}$, which account for $>50 \%$ of the elements in solution. This means that the evaluated materials can easily provide these ions. On the other hand, a high concentration saturation of these compounds may lead to the precipitation of secondary minerals. Therefore, the ion concentration in the saturation extracts was used to perform an evaluation on the tendency toward precipitation or dissolution of minerals (Figure S3 in the electronic supplement). The secondary minerals that can probably precipitate according to their positive saturation index are Huntite $\left(\mathrm{Mg}_{3} \mathrm{Ca}\left(\mathrm{CO}_{3}\right)_{4}\right.$ and Calcite $\left(\mathrm{CaCO}_{3}\right)$. This condition is very evident in Technosols produced from concrete waste $\left(\mathrm{C}_{55}, \mathrm{C}_{45}\right.$ and $\left.\mathrm{C}_{35}\right)$. It seems that concrete waste Technosols are more enriched in $\mathrm{Mg}^{2+}$ than excavation waste, and therefore dissolves faster and forms secondary minerals when applied in greater proportion. Moreover, $\mathrm{E}_{55} \mathrm{O}_{10}$ has not presented a tendency for precipitation of new mineral species and this is probably due to the fact that this soil-like material has larger clay contents capable of retaining cations present in solution. All of these aspects are still poorly documented for Technosols, thus the study of the weathering processes of these materials must be deepened in order to address the potential availability of major plant nutrients. The total contents of carbon and nitrogen also increased as a function of compost application rate $(\mathrm{p}<0.05)$ and, particularly, the demolition-based Technosol amended with the highest rate of compost $\left(\mathrm{D}_{35} \mathrm{O}_{30}\right)$ presented the highest contents of those compared to the other Technosols $(\mathrm{p}<0.05)$ (Table 2). The compost dose also had a significant effect on the concentrations of DOC, which increased by $206 \%$ in the Technosols with the highest compost addition compared to the lowest one $(\mathrm{p}<0.05)$ (Table S5, Figure S2), independent of the construction materials, which in turn did not provide changes in this property $(p>0.05)$ (Table S6). Indeed, large increases in soil DOC have been observed after compost additions with immediate effects attributed to dissolved organic matter of composts (Wright et al., 2008). Dissolved organic matter is 


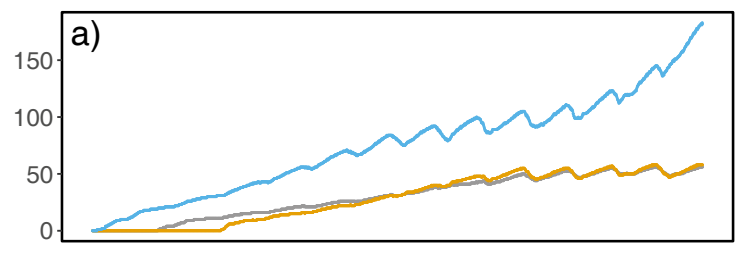

$$
\begin{aligned}
& -\mathrm{C}_{55} \mathrm{O}_{10} \\
& -\quad \mathrm{C}_{45} \mathrm{O}_{20} \\
& -\quad \mathrm{C}_{35} \mathrm{O}_{30}
\end{aligned}
$$

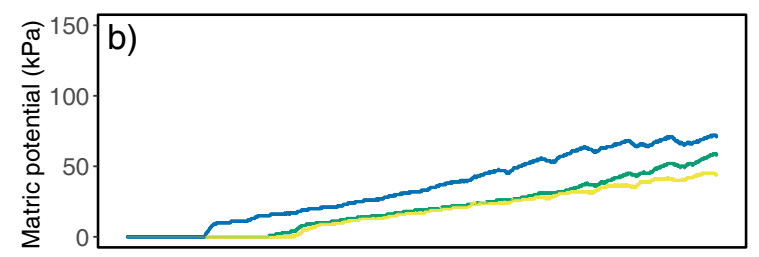

$\rightarrow \quad \mathrm{D}_{55} \mathrm{O}_{10}$

$-\quad \mathrm{D}_{45} \mathrm{O}_{20}$

$-\mathrm{D}_{35} \mathrm{O}_{30}$

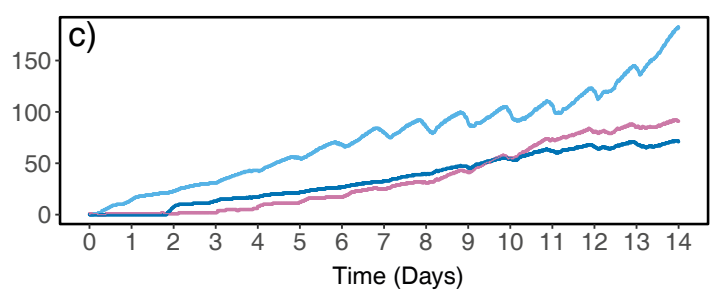

$-\mathrm{C}_{35} \mathrm{O}_{30}$

$-\mathrm{D}_{35} \mathrm{O}_{30}$

$\cdots \mathrm{E}_{35} \mathrm{O}_{30}$

Figure 6. Variation of matric potential overtime under greenhouse conditions in a) Concrete-based Technosols $\left(\mathrm{C}_{55} \mathrm{O}_{10}, \mathrm{C}_{45} \mathrm{O}_{20}\right.$ and $\left.\mathrm{C}_{35} \mathrm{O}_{30}\right)$; b) Demolition-based Technosols $\left(\mathrm{D}_{55} \mathrm{O}_{10}, \mathrm{D}_{45} \mathrm{O}_{20}\right.$ and $\left.\mathrm{D}_{35} \mathrm{O}_{30}\right)$; and c) Technosols with the highest rates of compost regardless of the parent material $\left(\mathrm{C}_{35} \mathrm{O}_{30}, \mathrm{D}_{35} \mathrm{O}_{30}\right.$ and $\left.\mathrm{E}_{35} \mathrm{O}_{30}\right)$. C is concrete; $\mathrm{D}$ is demolition; $\mathrm{E}$ is excavation; $\mathrm{O}$ is compost.

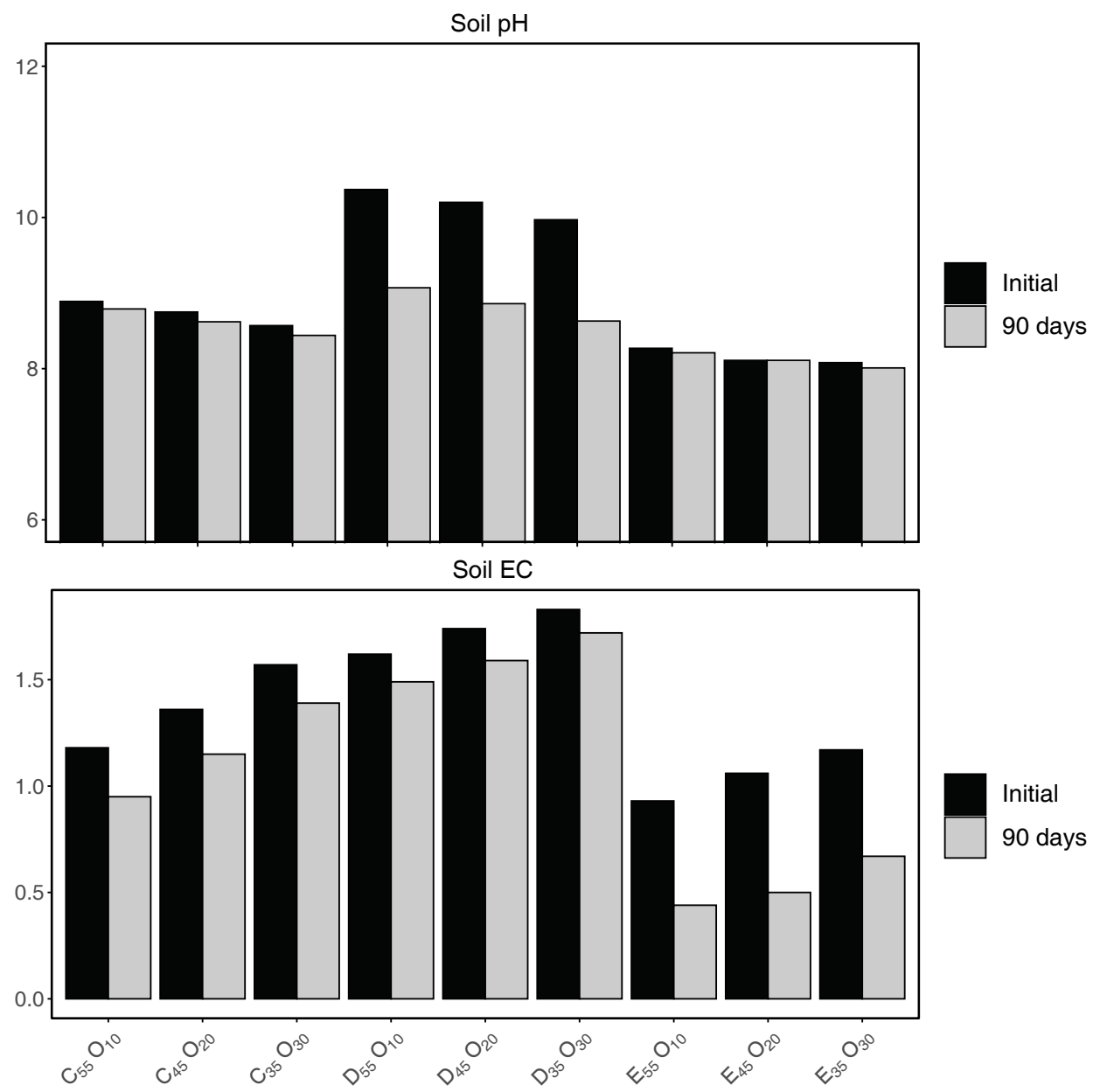

Figure 7. Initial and final (after 90 days of experiment) values of $\mathrm{pH}$ and $\mathrm{EC}\left(\mathrm{mS} \mathrm{cm}^{-1}\right)$ in the evaluated Technosols. $\mathrm{C}$ is concrete; $\mathrm{D}$ is demolition; $\mathrm{E}$ is excavation; $\mathrm{O}$ is compost. 
highly mobile in soils, which increases the risk of leaching of metals and nutrients, as ions complexed with dissolved organic matter can readily move through soil (Kaschl et al., 2002). Moreover, increasing concentration of DOC due to organic amendments may coat the surface of soil particles and reduce their ability to retain nutrients, thereby increasing their losses by leaching (Qualls and Haines, 1992). However, if the compost composition allows for rapid decomposition in soil, DOC may quickly return to background levels (Franchini et al., 2001).

\section{Metal contents in Technosols}

The deposition of heavy metals in road dust samples taken from urban, residential, commercial, industrial and highway sites has been well documented (Trujillo-González et al., 2016; Wei and Yang, 2010). Considering that the origin of the waste used in Technosols is urban, the risk of contamination by trace metals in Technosols made from these materials is probably the main health and environmental concern (Säumel et al., 2012). The Technosols made from concrete and excavation wastes showed significantly higher concentrations of soluble Fe and Mn compared to Technosols made from demolition waste ( $\mathrm{p}<0.05$ ) (Figure 9, Table S7 in the electronic supplement). The latter, in turn, had higher concentrations of $\mathrm{Mo}, \mathrm{Ni}$ and $\mathrm{V}$ compared to the other Technosols (Figure 9, Table S7). In all the cases, the concentrations of total $\mathrm{Cu}$ and $\mathrm{Ni}$ were below the limits established (100 and $60 \mathrm{mg} \cdot \mathrm{kg}^{-1}$, respectively) by international regulations on soils pol- luted by heavy metals (EPA, 2012; He et al., 2015). Additionally, the high $\mathrm{pH}$ values of both materials and the resulting Technosols led to higher metal solubility (Morel et al., 2005; Séré et al., 2008). However, potential co-transport of these elements with soluble organic matter should be considered in further research. On this regard, El Khalil et al. $(2008,2016)$ reported that the progressive alteration of coarse technic materials contributes to the enrichment of the soil solution by metallic pollutants. However, this alteration requires a long period of time, depending on several factors such as the nature of these materials, as well as the soil physicochemical and biological properties.

\section{Functioning of Technosols as plant growth media}

Soil fertility depends on the interaction of the chemical, physical and biological properties, which determine the ability to provide nutrients and water, as well as an adequate physical medium for the development of the roots. The optimal conditions for plant growth are not unique; it depends on the demand of each species, fertility, and external conditions such as the availability of water for irrigation or rain. Of the chemical variables, $\mathrm{pH}$ is considered the most important, since it influences the availability of nutrients, biological processes, and microbial activity. In the majority of cultivated species, values between 5.5 and 7.5 are proposed to favor the availability of nutrients for the plants. In the case of physical variables, aeration and water availability are the most important. The results of this research show
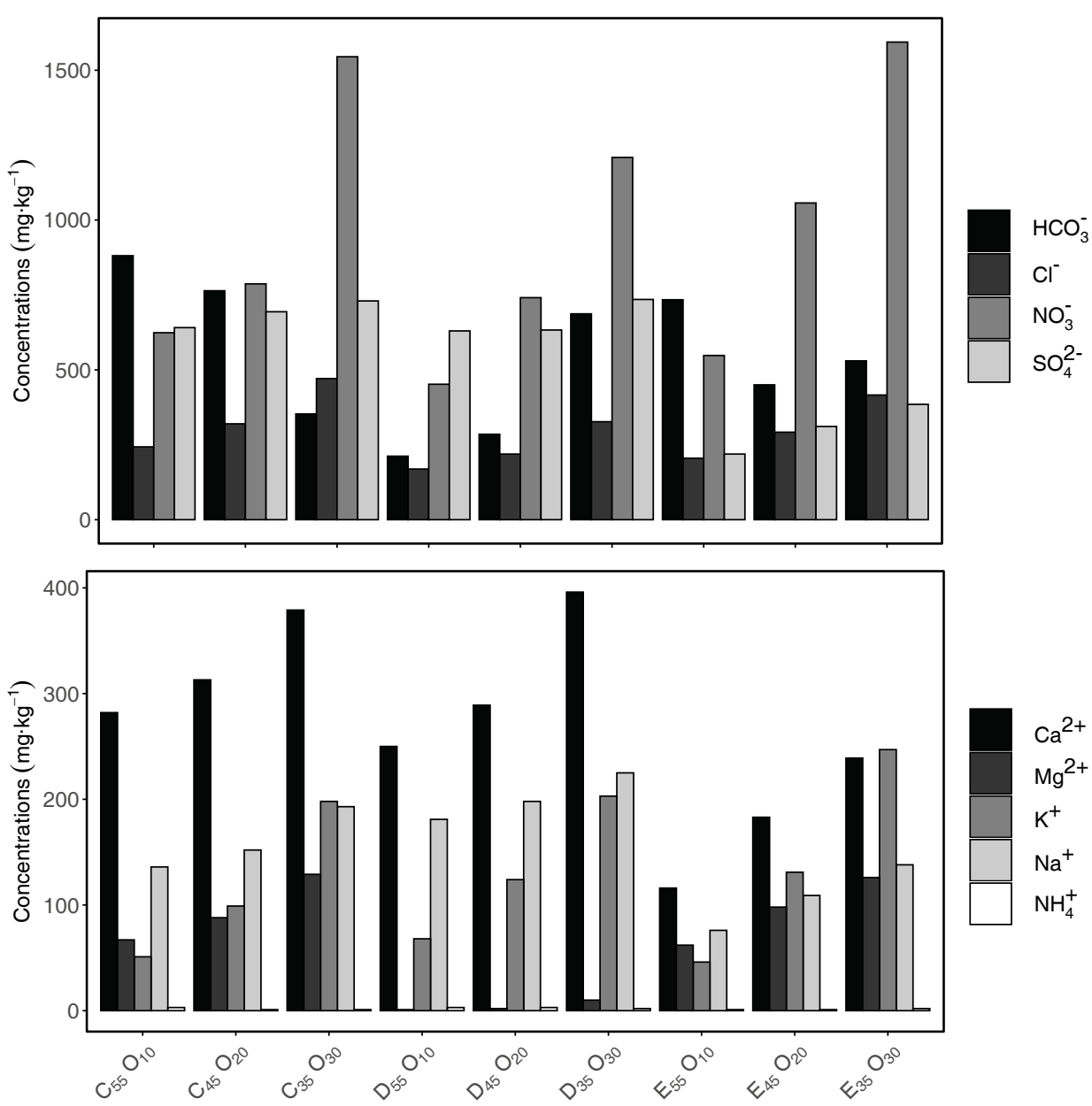

Figure 8. Distribution of major soluble ions in saturation paste extracts in concrete-, demolition- and excavation-based Technosols. C is concrete; D is demolition; $\mathrm{E}$ is excavation; $\mathrm{O}$ is compost. 


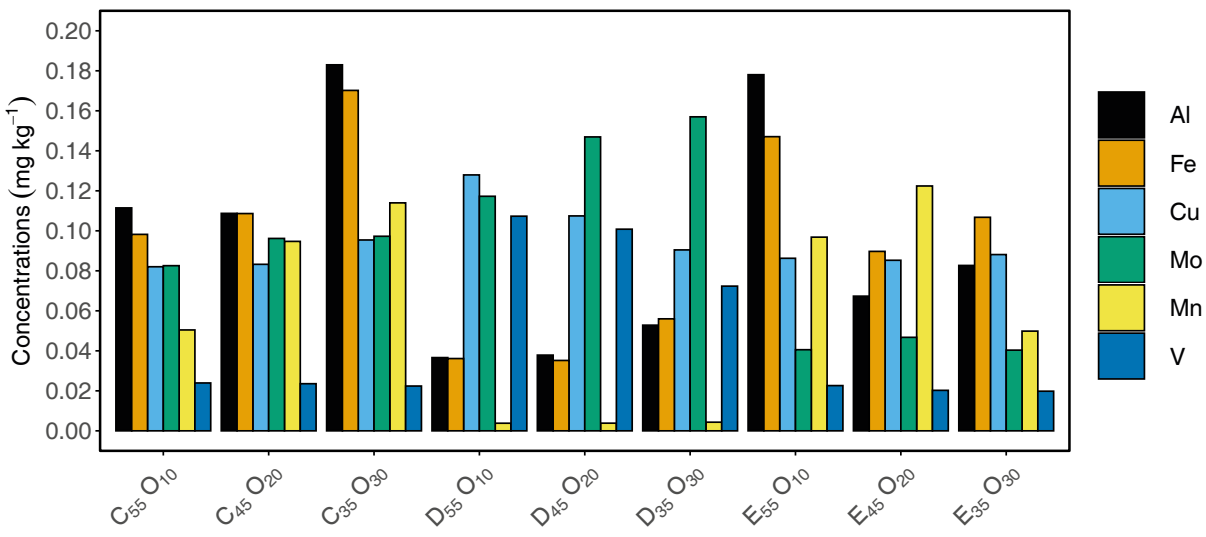

Figure 9. Concentrations of readily available heavy and trace metals in the studied Technosols. C is concrete; $\mathrm{D}$ is demolition; $\mathrm{E}$ is excavation; $\mathrm{O}$ is compost.

that the evaluated Technosols, have both, the physical and chemical variables adequate to the plant growth.

After 90 days of experiment, it was observed that the excavationbased Technosols $\left(\mathrm{E}_{55}, \mathrm{E}_{45}\right.$ and $\left.\mathrm{E}_{35}\right)$ led to a significant increase in plant growth and biomass production, which were 28 and $100 \%$ higher, respectively, compared to what was observed for Technosols based on demolition waste $\left(\mathrm{D}_{55}, \mathrm{D}_{45}\right.$ and $\left.\mathrm{D}_{35}\right)(\mathrm{p}<0.05)$, which, in turn, presented the lowest values of both parameters (Figure 10, Table S8 in the electronic supplement). Moreover, the rates of compost applied to Technosols did not have a significant effect on both height and aboveground biomass production ( $\mathrm{p}>0.05$ ) (Figure 10, Table S9).

The GLM analysis showed a significant effect of $\mathrm{EC}$ and total $\mathrm{N}$ content $\left(\mathrm{P}<0.01\right.$, adjusted $\left.\mathrm{R}^{2}=0.89\right)$ on the final height of tomato plants. Similarly, the $\mathrm{pH}$ and total $\mathrm{N}$ content had a high and significant effect
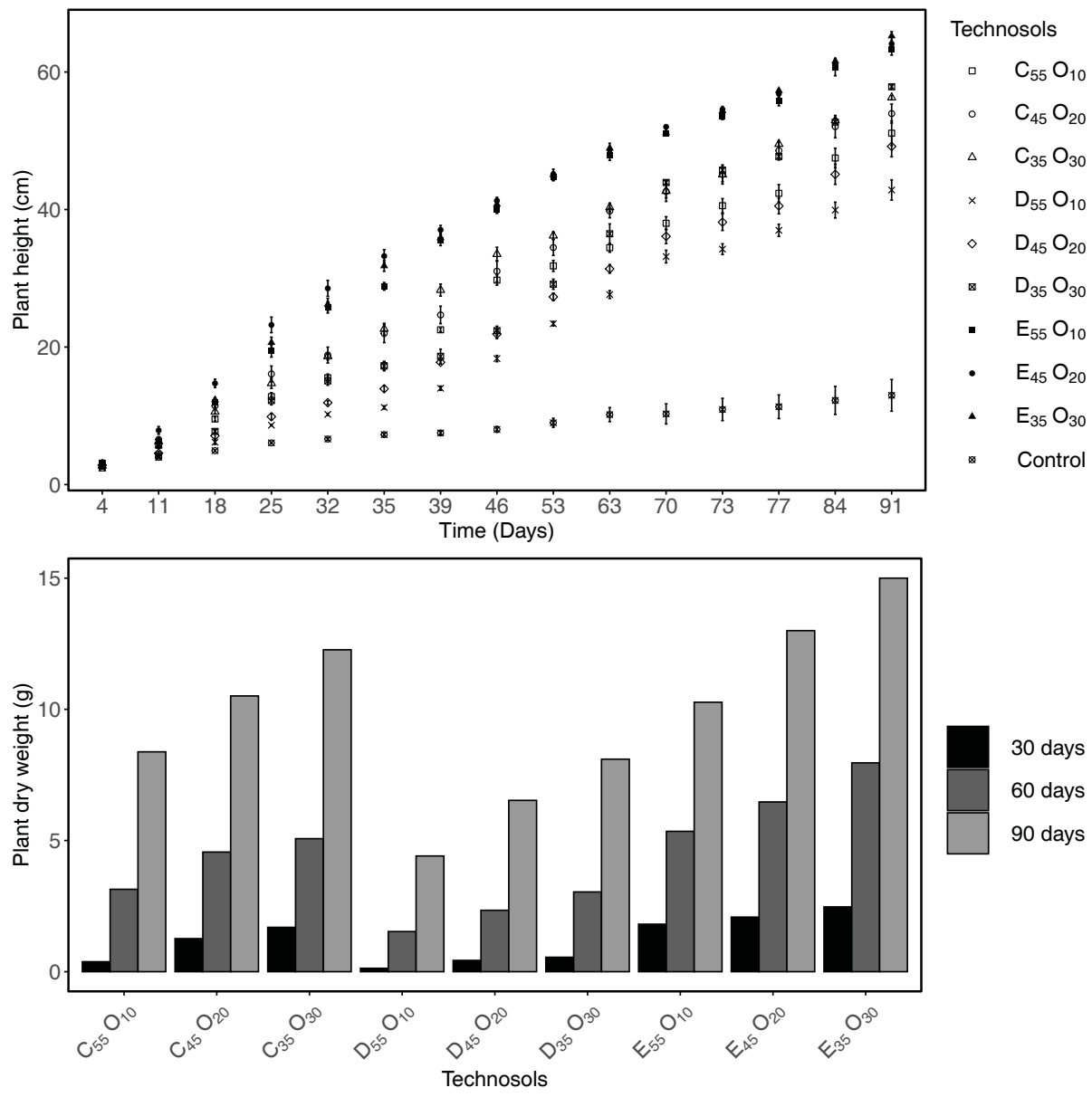

Figure 10. Height and dry weight of tomato plants grown in the evaluated Technosols over the experimental period (90 days). C is concrete; D is demolition; $\mathrm{E}$ is excavation; $\mathrm{O}$ is compost. 
( $\mathrm{P}<0.001$, adjusted $\left.\mathrm{R}^{2}=0.96\right)$ on plant dry weight. Thus, these results show that the excavation-based Technosol, by presenting less alkaline $\mathrm{pH}$ and EC, has a positive effect on the growth of the plants analyzed. The $\mathrm{pH}$ values of demolition-based Technosols (of about 9 units) suggest that the plants should be limited by nutrients as $\mathrm{P}, \mathrm{Fe}, \mathrm{Zn}, \mathrm{Cu}$.

Due to the lack of natural soils within cities and given that soil cannot be considered to be a readily renewable resource that can be excavated and easily transported from rural to urban areas (Walsh et al., 2019), this result highlights the purpose of making Technosols as plant-growth substrates, especially in the case of Technosols from construction debris and excavation wastes. The fact that this soil-like material, which is extracted within urban areas, offers adequate conditions for plant growth and biomass production, brings an encouraging perspective regarding the end-uses of the Technosols produced.

\section{Characteristics of Technosols with respect to the materials used in their construction}

A Principal Component Analysis (PCA) was made in order to explore the interactions between physical, chemical and physicochemical variables of Technosols related to the materials used in their construction. The analysis explained $86 \%$ of the variance in data (Figure 11, Table S10 in the electronic supplement).

For the first component, high coefficients were given to soil $\mathrm{pH}$ and EC, soil particle density, concentrations of soluble $\mathrm{Fe}, \mathrm{Mn}, \mathrm{Ni}$, $\mathrm{V}$ and Mo, concentrations of soluble $\mathrm{Mg}^{2+}$ and $\mathrm{Na}^{+}$, soil $\mathrm{C} / \mathrm{N}$ ratio, plant height and biomass (Figure 11, Table S10). The Technosols are distributed along PC1 in three separated groups that differed regarding their primary materials; demolition debris; waste concrete and excavation residues. In other words, the variables described above

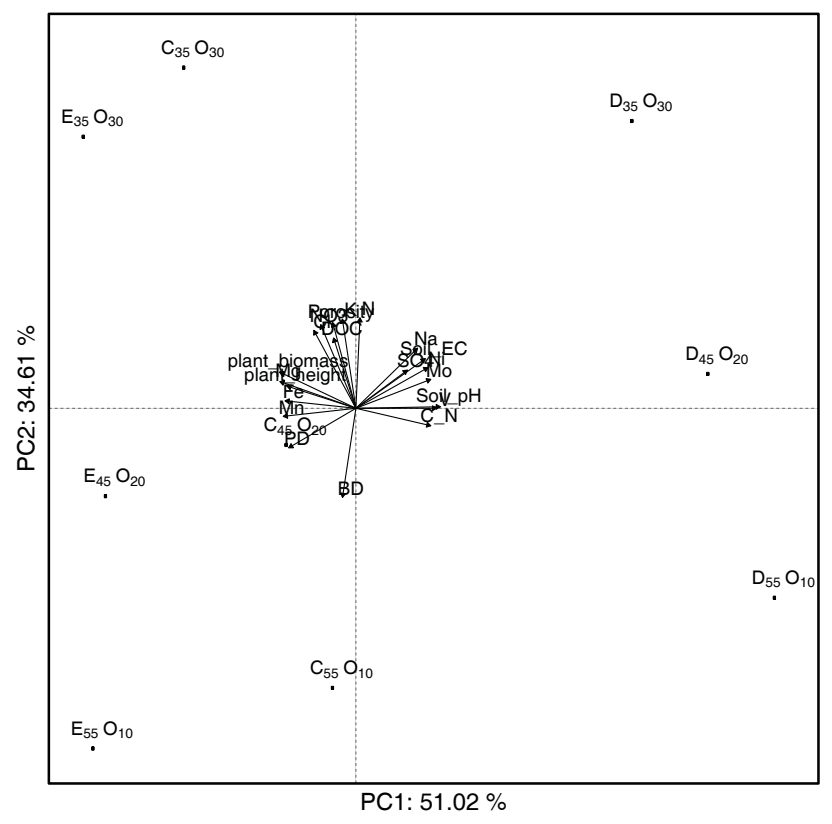

Figure 11. Principal Component Analysis for physical, chemical and physicochemical variables of nine Technosols produced from construction wastes enhanced with compost. $\mathrm{C}$ is concrete; $\mathrm{D}$ is demolition; $\mathrm{E}$ is excavation; $\mathrm{O}$ is compost. BD: Bulk Density; Cl: Soluble Cl; C N: C-to-N ratio; DOC: Dissolved organic carbon; Fe: Soluble Fe; K: Soluble K; Mg: Soluble Mg; Mn: Soluble Mn; Mo: Soluble Mo; Na: Soluble Na; Ni: Soluble Ni; NO3: Nitrate-N; PD: Particle Density; Plant biomass: Plant biomass; Plant height: Plant height: Porosity: Soil Porosity; SO4: Soluble $\mathrm{SO}_{4}{ }^{2-}$; Soil EC: soil electrical conductivity; Soil pH: Soil pH; TN: Total Nitrogen; V: Soluble V. are the most important for the formation of these three groups and, thus, they relate to the effects of the type of material used to construct each Technosol on physical, chemical and physicochemical attributes. Moreover, the points that relate to the Technosols from concrete waste and excavation residues are presented in a closer position when compared to the Technosols from demolition debris, indicating that the two first Technosols may share some similar characteristics compared to the third one.

As for the second principal component, high coefficients were given to bulk density and porosity, concentrations of total $\mathrm{N}$ and DOC, and concentrations of soluble $\mathrm{K}^{+}, \mathrm{NO}_{3}{ }^{-}$and $\mathrm{Cl}^{-}$. The Technosols are distributed along PC2 into three separate groups as a function of application rates of compost, regardless the type of material used to construct the Technosols (Figure 11, Table S10). Thus, the variables with significant correlations with PC2 described above are the most important for the formation of these three groups and they relate to the effects of compost application rates used to construct the Technosols on physical, chemical and physicochemical attributes.

In brief, a higher number of variables were related to the type of parent material (15 variables in PC1) compared to the doses of compost regardless of the parent material (seven variables in PC2), highlighting the effects of the former on changes in soil properties (Table S10). Moreover, soil $\mathrm{pH}$ appeared to be the main variable to distinguish the Technosols according to the type of parent material, while total $\mathrm{N}$ was more important in separating Technosols according to the application rates of compost (Table S10).

\section{CONCLUSIONS}

The constructed Technosols were suitable, to a greater or lesser extent, for tomato plant growth. The demolition waste turned out to be less suitable for the construction of custom-made Technosols in terms of plant growth and support: its high $\mathrm{EC}$ and $\mathrm{pH}$ values indicated high salinity and low availability of nutrients. Moreover, the small-pore size of this waste indicated higher compactability.

The main factors defining the suitability of the waste materials used in the construction of Technosols were soil $\mathrm{pH}$ and $\mathrm{EC}$ values. Both parameters changed over time due to the washing of salts. All the evaluated Technosols were adequate for the growth of tomato plants, however, the lowest growths were observed in demolition-based Technosols, due to the higher $\mathrm{pH}$ and $\mathrm{EC}$ values observed in these soils. The water holding capacity and soil aeration were adequate for plant growth; they were the result of the particle size of the mineral materials used in the construction of the Technosols, as well as the application rates of compost.

The application rates of compost defined the nutrient contents available for plant uptake and favor the macroporosity, besides increasing the aeration capacity to Technosols. Meanwhile, the type of parental materials defined the majority of the characteristics of Technosols as well as their ability to function as a plant support and growth medium.

The concentrations of readily available heavy and trace metals were not a limitation in the construction of Technosols for plant growth. However, potential co-transport of these elements with soluble organic matter should be considered in further research.

\section{ACKNOWLEDGMENTS}

This research was funded by the National Autonomous University of Mexico (UNAM) though Project PAPIIT IN108118. The authors thank the company Concretos Reciclados S.A. de C.V., for providing 
the construction wastes materials used in the investigation. The authors would like to thank Iris Suárez, Olivia Zamora, Maricarmen Salazar, Javier Tadeo, and René Alcalá; the Laboratorio Nacional de Geoquímica y Mineralogía (LANGEM), and the Laboratorio Universitario de Nanotecnología Ambiental (LUNA) UNAM for their technical support. Constructive reviews by Elizabeth Andrade Limas and Luke Beesley helped to improve the manuscript.

\section{SUPPLEMENTARY MATERIAL}

Supporting supplementary Tables S1 to S10 and Figures S1, S2 S3, can be found at the journal web site $<$ http://rmcg.unam.mx/ $>$, in the $\mathrm{html}$ version of this paper.

\section{REFERENCES}

Alfaia, R.G. de S., Costa, A.M., Campos, J.C., 2017, Municipal solid waste in Brazil: A review: Waste Management and Research, 35(12) 1195-1209.

Blake, G.R., 1965, Bulk density, in Black, C.A. (ed.) Methods of Soil Analysis: Part 1 Physical and Mineralogical Properties, Including Statistics of Measurement and Sampling, 9.1: Madison, WI, Agronomy Monographs, 374-390 pp.

Cannavo, P., Vidal-Beaudet, L., Grosbellet, C., 2014, Prediction of long-term sustainability of constructed urban soil: impact of high amounts of organic matter on soil physical properties and water transfer: Soil Use Management, 30, 272-284.

Cámara Mexicana de la Industria de la Construcción (CMIC), 2018, Plan de manejo de Residuos de la Construcción y la Demolición, 99 pp., available at $<$ https://www.cmic.org.mx/comisiones/Sectoriales/medioambiente/ Flayer/PM\%20RCD\%20Completo.pdf $>$, accessed april, 2020.

Davlasyan, N., 2020, Moscú estrena su inédito programa de reciclaje para luchar contra la basura: Euronews, available at $<$ https://es.euronews. com/2020/01/03/>, accessed may, 2020.

De Kimpe, C.R., Morel, J.L., 2000, Urban Soil Management: A growing concern: Soil Science, 165, 31-40.

Deeb, M., Grimaldi, M., Lerch, T.Z., Pando, A., Gigon, A., Blouin, M., 2016, Interactions between organisms and parent materials of a constructed Technosol shape its hydrostructural properties: Soil, 2, 163-174.

Díaz-Rodríguez, J.A., 2006, Los suelos lacustres de la ciudad de México: Revista Internacional de Desastres Naturales, Accidentes e Infraestructura Civil, 6, 111-129.

El Khalil, H., Schwartz, Ch., El Hamiani, O., Kubiniok, J., Morel, J.L., Boularbah, A., 2008, Contribution of technic materials to the mobile fraction of metals in urban soils in Marrakech (Morocco): Journal of Soil Sediments, 8, 17-22.

El Khalil, H., Schwartz, Ch., El Hamiani, O., Sirguey, C., Kubiniok, J., Boularbah, A., 2016, How physical alteration of technic materials affects mobility and phytoavailabilty of metals in urban soils?: Chemosphere, 152: 407-414.

Environment Protection Authority of Australia (EPA), 2012, Classification and management of contaminated soil for disposal. Hobart, TAS 7001, Australia Information Bulletin, 105, 12 pp.

Eurostat Statistics Explained, Waste statistics 2020, available at <https:// ec.europa.eu/eurostat/statisticsexplained/>, accessed april, 2020.

Federal Ministry for the Environment Nature Conservation and Nuclear Safety, 2020, Construction Wate, available at $<$ https://www.bmu.de/en/topics/ water-waste-soil/waste-management/types-of-waste-waste-flows/>, accessed april, 2020.

Flores Román, D., González Velázquez, A., Alcalá Martínez, J.R., Gamma Castro, J.E., 1991, Los Tepetates: Revista de Geografía, 3(4), 37-42.

Flores-Román, D., Muñiz-Irigoyen, C.G., Galicia-Palacios, M.S., FerreraCerrato, R., Zenteno, G., 2011, Enmiendas orgánicas y durazno, Prunus pérsica (L.) Batsch, en el mejoramiento de una capa endurecida, tepetate tipo duripán: Boletín de la Sociedad Geológica Mexicana, 63, 479-486.

Franchini, J.C., Gonzalez-Vila, F.J., Cabrera, F., Miyazawa, M., Pavan, M.A., 2001, Rapid transformations of plant water-soluble organic compounds in relation to cation mobilization in an acid oxisol: Plant and Soil, 231: 55-63.

Gálvez-Martos, J.L., Styles, D., Schoenberger, H., Zeschmar-Lahl, B., 2018, Construction and demolition waste best management practice in Europe: Resources, Conservation and Recycling, 136, 166-178.

Gee, G.W., Bauder, J.W., 1986, Particle size análisis, in Klute A. (ed.), Methods of Soil Analysis, Part 1: Madison, WI, Agronomy Monographs, 383-411.

Grard, B.J.P., Chenu, C., Manouchehri, N., Houot, S., Frascaria-Lacoste, N., Aubry, C., 2018, Rooftop farming on urban waste provides many ecosystem services: Agronomy for Sustainable Development, 38, 1-12.

Gregory, J.H., Dukes, M.D., Jones, P.H., Miller, G.L., 2006, Effect of urban soil compaction on infiltration rate: Journal of Soil and Water Conservation, 61(3), 117-124.

Greinert, A., 2015, The heterogeneity of urban soils in the light of their properties: Journal of Soils and Sediments, 15, 1725-1737.

Greinert, A., Kostecki, J., 2019, Anthropogenic materials ad bedrock of urban Technosols, in Vasenev V. et al. (eds.), SUITMA 2017: Moscow, Russia, Springer, 11-20.

Gruzen, S., City Green Inc., 2003, Construction \& Demolition waste manual. Prepared for NYC Department of Design and Construction, New Yotk, USA, $24 \mathrm{pp}$.

He, Z., Shentu, J., Yang, X., Baligar, V.C., Zhang, T., Stofella, P.J., 2015, Heavy metal contamination of soils: Sources, Indicators, and Assessment: Journal of Environmental Indicators 9, 17-18.

Iacoboaea, C., Aldea, M., Petrescu, F., 2019, Construction and demolition waste - A challenge for the European Union? Theoretical and Empirical Researches: Journal of Urban Management, 14, 30-52.

International Finance Corporation (IFC), 2012, Municipal solid waste management: Opportunities for Russia, available at $<$ http://www.ifc. org > accessed april, 2020.

Jacobi, P.R., Besen, G.R., 2011, Solid waste management in Sao Paulo: challenges of sustainability: Estudios Avançados, 25(71), https://doi.org/10.1590/ S0103-40142011000100010.

Jordán, M.M., García-Sánchez, E., Almendro-Candel, M.B., Pardo, F., Vicente, A.B., Sanfeliu, T., Bech, J., 2017, Technosols designed for rehabilitation of mining activities using minespoils and biosolids. Ion mobility and correlations using percolation columns: Catena 148, 74-80.

Kaschl, A., Romheld, V., Chen, Y., 2002, The influence of soluble organic matter from municipal solid waste compost on trace metal leaching in calcareous soils: Science of the Total Environment, 291, 45-57.

Kawahigashi, M., 2017, Specific properties of soils underneath pavement construction, in Levin M.J., Kim K.H.J., Morel J.L., Burghardt W., Charzynski P., Shaw R.K. (eds.) on behalf of IUSS Working Group SUITMA, Soils within Cities: Stuttgart, Catena-Schweizerbart, 78-84.

Magnusson, S., Lundberg, k., Svedberg, B., Knutsson, S., 2015, Sustainable management of excavated soil and rock in urban areas - A literature review: Journal of Cleaner Production, 193, 18-25.

Mingming, H., 2010, Dynamic material flow analysis for strategic construction and demolition waste management in Beijing: Journal of Industrial Ecology, 14(3), 440-456.

Morel, J.L., Schwartz, C., Florentin, L., De Kimpe, C., 2005, Urban Soils, in Hillel, D. (ed.), Encyclopedia of Soils in the Environment: Academic Press, 202-208.

Morel, J.L., Chenu, C., Lorenz, K., 2015, Ecosystem services provided by soils of urban, industrial, traffic, mining, and military areas (SUITMAs): Journal of Soils Sediments, 15, 1659-1666.

Paradelo, R., Barral, M.T., 2013, Influence of organic matter and texture on the compatibility of Technosols: Catena, 110, 95-99.

Programa de Gestión Integral de Residuos Sólidos (PGIRS) 2016-2020, Secretaría del Medio Ambiente, available at <https://www.sedema.cdmx. gob.mx/storage/app/media/programas/residuos-solidos/pgirs.pdf>, accessed april 2020

Prat, C., Báez, A., Márquez, A., 1997, Erosión y escurrimiento en parcelas de Tepetate $t_{3}$ en Texcoco, México, in Zebrowski. C., Quantin, P., Trujillo, G, (eds.), Memorias del III Simposio Internacional sobre Suelos Volcánicos Endurecidos: Quito, Ecuador, 371-383.

Prieto García, F., Rangel Martínez, Y., Acevedo Sandoval, O.A., Gordillo Martínez, A.J., 2012, Recovery of Waste of Construction, Demolition and Mining Tailings: International Journal of Applied Science and Technology, 2(7), 46-63. 
Pruvost, C., 2018, Potentiel de la Biodiversité dans la construction de Technosols à partir de déchets urbains : Université Paris-Est; École doctorale Sciences, Ingénierieet Environnement Laboratoire: IEES Paris - Institut d'Ecologie et des Sciences de l'Environnement de Paris (laboratoire), Ph.D. thesis, 173 pp. http://www.theses.fr/s137684.

Qualls, R.G., Haines, B.L., 1992, Biodegradability of dissolved organic matter in forest through fall, soil solution, and stream wáter: Soil Science Society of America Journal, 56, 578-586.

R Core Team, 2020, R: A language and environment for statistical computing. R Foundation for Statistical Computing, Vienna, Austria, available at $<$ http://www.R-project.org/>.

Rojas Valencia, M.N., Macías Martínez, D.A., 2013, Manejo de los residuos de la construcción: Colegio de Ingenieros Civiles de México A.C., IC Ingeniería Civil, Junio, 530, 20-24.

Rokia, S., Séré, G., Schwartz, C., Deeb, M., Fournier, F., Nehls, T., Damas, O., Vidal-Beaudet, L., 2014, Modelling agronomic properties of Technosols constructed with urban wastes: Waste Management, 34, 2155-2162.

Säumel, I., Kotsyuk, I., Hölscher, M., Lenkereit, C., Weber, F., Kowarik, I., 2012. How healthy is urban horticulture in high traffic areas? Trace metal concentrations in vegetable crops from plantings within inner city neighbourhoods in Berlin, Germany. Environ Pollut, 165, 124-132.

Schinner, F., Öhlinger, R., Kandeler, E., Margesin, R., 1993, Bodenbiologische Arbeitsmethoden, 2nd ed.: Heidelberg, Germany, Springer Verlag, 426 pp.

Seki, K., 2007, SWRC fit - a nonlinear fitting program with a water retention curve for soils having unimodal and bimodal pore structure: Hydrology and Earth System Science Journal, 4, 407-437.

Séré, G., Schwartz, C., Ouvrard, S., Sauvage, C., Renat, J.C., Morel, J.L., 2008, Soil Construction: A Step for Ecological Reclamation of Derelict Lands: Journal of Soils Sediments, 8, 130-136.

Trujillo-González, J.M., Torres-Mora, M.A., Keesstra, S., Brevik, E.C., JiménezBallesta, R., 2016, Heavy metal accumulation related to population density in road dust samples taken from urban sites under different land uses: Science of the Total Environment, 553, 636-642.

United Nations (UN), 2018, Department of Economic and Social Affairs, Population division, 2018. The Worls Cities in 2018 Data Booklet (ST/ ESA/SER.A./417), 34 pp, available at <https://www.un.org/en/events/ citiesday/assets/pdf/the_worlds_cities_in_2018_data_booklet.pdf > consulted august 2020.

United Nations (UN), 2019, World Population Prospects Highlights: New York, USA, United Nations, Department of Economic and Social Affairs, Population Division, ST/ESA/SER.A/423, 46 pp. van Genuchten, M.T.,1980, A closed-form equation for predicting the hydraulic conductivity of unsaturated soils: Soil Science Society of America Journal 44, 892-898.

van Reeuwijk, L.P., 1992, Procedures for Soil Analysis. 3rd ed., International Soil Reference and Information Centre (ISRIC), Wageningen, $34 \mathrm{pp}$.

Vidal-Beaudet, L., Cannavo, P., Schwartz, C., Séré, G., Béchet, B., Legret, M., Peynau, P.E., Bataillard, P., Coussy, S., Damas, O., 2017, Using waste for fertile urban soil construction - The French Research Project SITERRE, in Levin, M.J., Kim, K.H.J., Morel, J.L., Burghardt, W., Charzynski, P., Shaw R.K. (eds.) on behalf of IUSS Working Group SUITMA, Soils within Cities: Stuttgart Catena-Schweizerbart, 159-168.

Villanueva, P.D., 2019, Ficha sector. Gestión de residuos sólidos urbanos en Rusia 2019: ICEX España Exportación e Inversiones, available at <https://www. icex.es/icex/es/DOC2019818022.html>, accessed May 8. 2020.

Walsh, D., McRae, I., Zirngib, R., Chawla, S., Zhang, H., Alfieri, A., Moore, H., Bailey, C., Brooks, A., Ostock, T., Pong, S., Hard, T., Sullivan, C., Wilding, J., 2019, Generation rate and fate of surplus soil extracted in New York City: Science of the Total Environment, 650, 3093-3100.

Wei, B., Yang, L., 2010, A review of heavy metal contaminations in urban soils, urban road dusts and agricultural soils from China: Microchemical Journal, 94, 99-107.

Wright, A.L., Provin, T.L., Hons, F.M., Zuberer, D.A., White, R.H., 2008, Compost impacts on dissolved organic carbon and available nitrogen and phosphorus in turfgrass soil: Journal of Waste Management, 28, 1057-1063.

Zhang, H., Hartge, K.H., Ringe, H., 1997, Effectiveness of organic matter incorporation in reducing soil compactibility: Soil Science Society of America Journal, 61, 239-245.

Zhao, W., Rottler, S., 2008, The current situation of construction \& demolition waste management in China, in 2008 2nd International Conference on Bioinformatics and Biomedical Engineering: Institute of electrical and electronics Engineers, Shanghai, China, 4747-4750.

Manuscript received: june 10, 2020

Corrected manuscript received: september 27, 2020

Manuscript accepted: september 29, 2020 